\title{
Risk factors and myocardial infarction in patients with obstructive sleep apnea: impact of $\beta 2$-adrenergic receptor polymorphisms
}

\author{
Nina K Bartels ${ }^{\dagger 1}$, Jan Börgel ${ }^{* \dagger 2}$, Stefan Wieczorek ${ }^{1}$, Nikolaus Büchner ${ }^{3}$, \\ Christoph Hanefeld ${ }^{2}$, Daniel Bulut ${ }^{2}$, Andreas Mügge ${ }^{2}$, Lars C Rump', \\ Bernd M Sanner ${ }^{4}$ and Jörg T Epplen ${ }^{1}$
}

Address: ${ }^{1}$ Human Genetics, Ruhr-University Bochum, Germany, ${ }^{2}$ Medical Clinic II Cardiology and Angiology, St. Josef-Hospital/Bergmannsheil, Ruhr-University Bochum, Germany, ${ }^{3}$ Medical Clinic I, Marien-Hospital Herne, Ruhr-University Bochum, Germany and ${ }^{4}$ Medical Clinic, BethesdaHospital, Wuppertal, Germany

Email: Nina K Bartels - the_sirius@web.de; Jan Börgel* - jan.boergel@rub.de; Stefan Wieczorek - stefan.wieczorek@rub.de; Nikolaus Büchner - nikolaus.buechner@rub.de; Christoph Hanefeld - christoph.hanefeld@rub.de; Daniel Bulut - daniel.bulut@rub.de; Andreas Mügge - andreas.muegge@rub.de; Lars C Rump - christian.rump@rub.de; Bernd M Sanner - bernd.sanner@bethesda-wuppertal.de; Jörg T Epplen - joerg.t.epplen@rub.de

* Corresponding author †Equal contributors

Published: I January 2007

BMC Medicine 2007, 5:I doi:10.1186/1741-7015-5-I
Received: 24 July 2006

Accepted: I January 2007

This article is available from: http://www.biomedcentral.com/I74I-70I5/5/I

(C) 2007 Bartels et al; licensee BioMed Central Ltd.

This is an Open Access article distributed under the terms of the Creative Commons Attribution License (http://creativecommons.org/licenses/by/2.0), which permits unrestricted use, distribution, and reproduction in any medium, provided the original work is properly cited.

\begin{abstract}
Background: The increased sympathetic nervous activity in patients with obstructive sleep apnea (OSA) is largely responsible for the high prevalence of arterial hypertension, and it is suggested to adversely affect triglyceride and highdensity lipoprotein $(\mathrm{HDL})$ cholesterol levels in these patients. The functionally relevant polymorphisms of the $\beta 2$ adrenergic receptor (Arg-47Cys/Argl6Gly and Gln27Glu) have been shown to exert modifying effects on these risk factors in previous studies, but results are inconsistent.
\end{abstract}

Methods: We investigated a group of 429 patients ( $55 \pm 10.7$ years; $36 \mathrm{I}$ men, 68 women) with moderate to severe obstructive sleep apnea (apnea/hypopnea index (AHI) $29.1 \pm 23.1 / \mathrm{h}$ ) and, on average, a high cardiovascular risk profile (body mass index $31.1 \pm 5.6$, with hypertension in $60.1 \%$, dyslipidemia in $49.2 \%$, and diabetes in $17.2 \%$ of patients). We typed the $\beta 2$-adrenergic receptor polymorphisms and investigated the five most frequent haplotypes for their modifying effects on OSA-induced changes in blood pressure, heart rate, and lipid levels. The prevalence of cardiovascular risk factors and coronary heart disease $(n=55,12.8 \%)$ and survived myocardial infarction $(n=27,6.3 \%)$ were compared between the genotypes and haplotypes.

Results: Multivariate linear/logistic regressions revealed a significant and independent (from BMI, age, sex, presence of diabetes, use of antidiabetic, lipid-lowering, and antihypertensive medication) influence of $\mathrm{AHI}$ on daytime systolic and diastolic blood pressure, heart rate, prevalence of hypertension, and triglyceride and HDL levels. The $\beta 2$-adrenergic receptor genotypes and haplotypes showed no modifying effects on these relationships or on the prevalence of dyslipidemia, diabetes, and coronary heart disease, yet, for all three polymorphisms, heterozygous carriers had a significantly lower relative risk for myocardial infarction (Arg-47Cys: $n=195$, odds ratio $(O R)=0.32, P=0.012$; Arg16Gly: $n=197, O R=0.39, P=0.031$; Gln27Glu: $O R=0.37, P=0.023)$. Carriers of the most frequent haplotype $(n$ = II3) (haplotype I; heterozygous for all three polymorphisms) showed a five-fold lower prevalence of survived myocardial infarction $(O R=0.21, P=0.023)$.

Conclusion: Our study showed no significant modifying effect of the functionally relevant $\beta 2$-adrenergic receptor polymorphisms on OSA-induced blood pressure, heart rate, or lipid changes. Nevertheless, heterozygosity of these polymorphisms is associated with a lower prevalence of survived myocardial infarction in this group with, on average, a high cardiovascular risk profile. 


\section{Background}

Patients with obstructive sleep apnea (OSA) show increased sympathetic nervous activity during both night and day [1-3]. This increased sympathetic activity may contribute to arterial hypertension, increased heart rate $[4,5]$, and dyslipidemia [6,7]. In addition to exacerbation of these cardiovascular risk factors, the elevated sympathetic activity makes patients with OSA vulnerable to both fatal and non-fatal coronary events [8-10]. Sympathetic activity is mediated by $\beta 2$-adrenergic receptors, among others. The receptors are expressed in a wide variety of tissues, including the vascular and bronchial smooth muscles, the heart, and adipocytes. Thus, $\beta 2$-adrenergic receptors play a critical role in the regulation of blood pressure (BP), heart rate, and lipid metabolism. Several polymorphisms of the $\beta 2$-adrenergic receptor gene have been identified. For three polymorphisms, which are the subject of the present study, functional consequences have been described [11]:

1) At position -47 in the untranslated region of the $\beta 2$ adrenergic receptor gene, a cytosine $(\mathrm{C})$ /thymine $(\mathrm{T})$ polymorphism results in either arginine (Arg) or cystine (Cys) in the 5' leader sequence. This sequence encodes a peptide that modifies $\beta 2$-adrenergic receptor gene translation. In human airway smooth muscles, the Cys variant showed a consistently greater expression of the $\beta 2$-adrenergic receptor $[12,13]$.

2) At position 46 of the coding region, adenine (A) or guanine $(\mathrm{G})$ can be found, resulting in arginine (Arg) or glycine (Gly) at amino acid position 16 .

3) At nucleotide position 79, a C/G polymorphism results in glutamate (Glu) or glutamine (Gln) at amino acid position 27.

The latter two polymorphisms and their haplotypes modify the down-regulation of the $\beta 2$-adrenergic receptor upon agonist stimulation. In a previous study [14], the Gly16/Gln27 haplotype underwent enhanced down-regulation compared with the Arg16/Gln27 haplotype, while the Arg16/Glu27 haplotype showed almost no down-regulation. Many population-based studies have been performed to investigate the modifying potency of these polymorphisms on cardiovascular risk factors in vivo, but the results have been inconsistent or contradictory.

Previously, a significant negative influence of the severity of OSA on BP, prevalence of arterial hypertension, heart rate, and serum levels of high-density lipoprotein cholesterol (HDL-C) was shown in the parent study cohort of the patients $[4,7]$ included in this report. In the present study, we scrutinised the modifying effects of $\beta 2$-adrenergic receptor polymorphisms on these risk factors, which are mediated by elevated sympathetic activity. We further investigated whether the three polymorphisms have an effect on the comparatively high prevalence of coronary heart disease (CHD) and survived myocardial infarction (MI) in our patients with OSA.

\section{Methods \\ Patients and parent study data}

The study protocol was approved by the local ethics committee (Ruhr-University Bochum, Germany). Patients were consecutively enrolled during the years 1999 to 2001 in the sleep laboratory of the Marienhospital, Herne, Ruhr-University Bochum, Germany. The patients were admitted to the hospital because of a history of apnea, snoring, or hypersomnic symptoms such as daytime tiredness or impairment of cognitive functions.

Detailed information on the determination of cardiac risk factors and polysomnography have been described extensively in previous publications [4,7]. In brief, after informed consent, the severity of OSA was assessed using the apnea/hypopnea index (AHI). Dyslipidemia was diagnosed by the presence of anamnesis and use of lipid-lowering drugs or presence of dyslipidemic serum levels. For blood analysis, the following cut-off values were defined as abnormal: total cholesterol $\geq 200 \mathrm{mg} / \mathrm{dL}$, triglycerides $\geq 180 \mathrm{mg} / \mathrm{dL}$, HDL-C $\leq 40 \mathrm{mg} / \mathrm{dL}$, and low-density lipoprotein cholesterol (LDL-C) $\geq 150 \mathrm{mg} / \mathrm{dL}$. Diabetes was defined by presence of anamnesis and use of antidiabetic medication or insulin treatment. The diagnosis of hypertension was established by use of antihypertensive medication or if the mean of three measured BP readings exceeded $140 \mathrm{mmHg}$ (systolic) or $90 \mathrm{mmHg}$ (diastolic).

\section{Genotyping}

Peripheral blood samples from the patients were taken after they had given informed consent.

The following primers were synthesised to amplify a 283 bp fragment containing the Cys-47Arg polymorphism: 5'AATGAGGCTTCCAGGCGTC-3' (sense) and 5'-ACTTGGCAATGGCTGTGATG-3' (antisense). PCR was carried out in a final volume of $10 \mu \mathrm{L}$ with $50 \mathrm{ng}$ DNA, $2 \mathrm{mM}$ dNTPs and 1 U Taq polymerase. PCR cycling started with initial denaturation for 5 minutes at $94^{\circ} \mathrm{C}$. The annealing temperature of the first cycle was $69^{\circ} \mathrm{C}$, second cycle $66^{\circ} \mathrm{C}$ and the remaining 28 cycles $63^{\circ} \mathrm{C}$, each cycle being 1 minute. Extension was performed at $72^{\circ} \mathrm{C}$ for 1 minute (final extension 5 minutes). Allele-specific restriction digests were performed with MspAII, which fails to digest the Cys- 47 allele because of the $\mathrm{C} \rightarrow \mathrm{G}$ transition. Digested DNA was separated by electrophoresis on $1.5 \%$ agarose gels. 
For the Gly16Arg polymorphism, the following primers were synthesised to obtain a 96-bp fragment: 5'-GCCAGTGCGCTTACCTGC-3' (sense) and 5'-TGGTCCGGCGCATGGCTT-3' (antisense). Final volume of the PCR was 10 $\mu \mathrm{L}$, containing 50 ng DNA, $2 \mathrm{mM}$ dNTPs, $1 \mathrm{U}$ Taq polymerase and $1 \%$ radioactively labelled dATP. The PCR cycles after denaturation $\left(94^{\circ} \mathrm{C}\right.$ for 5 minutes) were $70^{\circ} \mathrm{C}$ ( 1 cycle), $67^{\circ} \mathrm{C}$ ( 1 cycle) and $64^{\circ} \mathrm{C}(28$ cycles $)$, with each cycle lasting 1 minute. Extension at $72^{\circ} \mathrm{C}$ was performed for 1 minute, and 5 minutes at the end. The PCR products were digested with the restriction endonuclease $\mathrm{NcoI}$ in order to optimize the demonstration of the polymorphism by single-strand conformational polymorphism analysis. Restriction products were separated in an $8 \%$ polyacrylamide (19:1 acrylamide:bisacrylamide) gel containing $10 \%$ glycerol.

For genotyping the Gln27Glu polymorphism, the primers 5'-AAGCCATGCGCCGGACCA-3' (sense) and 5'-ACTTGGCAATGGCTGTGATG-3' (antisense) primers were chosen, which produce a 134-bp long product. PCR was performed with a final volume of $10 \mu \mathrm{L}$ comprising $50 \mathrm{ng}$ DNA, $2 \mathrm{mM}$ dNTP and $1 \mathrm{U}$ Taq polymerase. The chosen temperatures after denaturation were $70.5^{\circ} \mathrm{C}$ (1 cycle), $67.5^{\circ} \mathrm{C}$ ( 1 cycle $)$, and $64.5^{\circ} \mathrm{C}(28$ cycles $)$. Allele-specific restriction was performed with $B b v \mathrm{I}$ and bands separated in a $1.5 \%$ agarose gel.

\section{Statistical analysis}

Results are presented as means +/-SD. All reported $P$-values are two-tailed. Statistical analyses were performed with SPSS for Windows software (SPSS, Chicago, IL, USA). Multivariate linear regressions were calculated in order to determine independent associations between the AHI and $\mathrm{BP}$, heart rate and lipid serum levels in the presence of body mass index (BMI), age, and sex. The relationship between the severity of OSA represented by the AHI and the prevalence of arterial hypertension was calculated using multiple logistic regression analysis using BMI, age, and sex as covariates. Demographic characteristics of the patients with OSA were compared between the different genotypes using the $\chi^{2}$ test; $P<0.05$ was considered significant. The phenotypic values were compared between the genotypes using analysis of variance (ANOVA). Student's $t$-test for unpaired samples was used for comparisons between particular genotypes/haplotypes and the rest of the group.

An additional model was established in which the homozygous states of each polymorphism were pooled in one group and compared with the heterozygous genotype. The influence of heterozygosity of each polymorphism on survived MI was then analysed in a multivariate logistic regression model, adjusted for diabetes, dyslipidemia, hypertension, sex, BMI, AHI, and age.

\section{Results}

The prevalences of the three genotypes are shown in Table 1 , which also summarises the demographic findings in the full study group $(n=429)$, separated for the different genotypes of the $\beta 2$-adrenergic receptor polymorphisms.

Allele frequencies of the different polymorphisms were: Arg-47Cys $=0.53 / 0.47$, Arg16Gly $=0.37 / 0.63$ and Gln27Glu $=0.49 / 0.51$. The $\beta 2$-adrenergic receptor polymorphisms Arg-47Cys and Gln27Glu were found to be

Table I: Demographics in the different genotypes of the $\beta 2$-adrenergic receptor.

\begin{tabular}{|c|c|c|c|c|c|c|c|c|}
\hline Genotype & $\begin{array}{l}n^{*} \\
\text { (\% of all) }\end{array}$ & $\begin{array}{l}\text { Age } \\
\text { mean } \pm S D\end{array}$ & $\begin{array}{l}\text { BMI } \\
\text { mean } \pm S D\end{array}$ & $\begin{array}{l}\text { Hypertension } \\
n\left(\% \text { of } n^{*}\right)\end{array}$ & $\begin{array}{l}\text { Diabetes } \\
n\left(\% \text { of } n^{*}\right)\end{array}$ & $\begin{array}{l}\text { Dyslipidemia } \\
n(\% \text { of } n *)\end{array}$ & $\begin{array}{l}\text { CHD } \\
n\left(\% \text { of } n^{*}\right)\end{array}$ & $\begin{array}{l}\text { MI } \\
n\left(\% \text { of } n^{*}\right)\end{array}$ \\
\hline All & 429 & $55.2 \pm 10.7$ & $31.1 \pm 5.6$ & $258(60.1)$ & $74(17.2)$ & $211(49.2)$ & $55(12.8)$ & $27(6.3)$ \\
\hline \multicolumn{9}{|l|}{ Codon -47} \\
\hline Cys/Cys & $|3|(24.0)$ & $55.9 \pm 11.3$ & $30.8 \pm 5.2$ & $76(58.0)$ & $23(17.6)$ & $65(49.6)$ & $16(12.2)$ & II (8.4) \\
\hline Cys/Arg & $195(45.2)$ & $55.1 \pm 10.7$ & $31.1 \pm 6.0$ & $119(61.0)$ & $36(18.5)$ & 91 (46.7) & $25(12.8)$ & $6(3.1)$ \\
\hline Arg/Arg & $103(30.5)$ & $54.2 \pm 9.7$ & $31.5 \pm 5.6$ & $63(61.2)$ & $15(14.6)$ & $55(53.4)$ & $14(13.6)$ & $10(9.7)$ \\
\hline$P$ & & 0.512 & 0.705 & 0.837 & 0.694 & 0.539 & 0.952 & 0.040 \\
\hline \multicolumn{9}{|l|}{ Codon 16} \\
\hline Arg/Arg & $59(13.8)$ & $57.0 \pm 9.9$ & $31.6 \pm 6.0$ & $34(57.6)$ & $12(20.8)$ & $30(50.8)$ & $6(10.9)$ & $6(10.2)$ \\
\hline Arg/Gly & $197(45.9)$ & $54.0 \pm 11.1$ & $31.1 \pm 6.0$ & 121 (6I.4) & 35 (17.8) & 95 (48.2) & $23(11.7)$ & $7(3.6)$ \\
\hline Gly/Gly & $173(40.3)$ & $54.7 \pm 10.5$ & $31.0 \pm 5.0$ & $103(59.5)$ & $27(15.6)$ & $86(49.7)$ & $26(15.0)$ & $14(8.1)$ \\
\hline$P$ & & 0.347 & 0.790 & 0.854 & 0.684 & 0.924 & 0.507 & 0.084 \\
\hline \multicolumn{9}{|l|}{ Codon 27} \\
\hline $\mathrm{Gln} / \mathrm{Gln}$ & $109(25.4)$ & $55.9 \pm 11.0$ & $31.5 \pm 5.4$ & $67(6 \mid .5)$ & $23(2 \mathrm{I} . \mathrm{I})$ & $60(55.0)$ & $16(14.7)$ & $13(11.9)$ \\
\hline Gln/Glu & $202(47.1)$ & $56.0 \pm 10.5$ & $31.0 \pm 6.0$ & $117(57.9)$ & $33(16.3)$ & $88(43.6)$ & 24 (11.9) & $7(3.5)$ \\
\hline Glu/Glu & $118(27.5)$ & $52.9 \pm 10.5$ & $30-9 \pm 5.2$ & $74(62.7)$ & $18(15.3)$ & $63(53.4)$ & $15(12.7)$ & $7(5.9)$ \\
\hline$P$ & & 0.031 & 0.746 & 0.663 & 0.454 & 0.087 & 0.391 & 0.013 \\
\hline
\end{tabular}

Demographics of the study group $(n=429)$ and its subgroups with the different genotypes of the $\beta 2$-adrenergic receptor polymorphisms. Statistical tests that revealed $P$-values below 0.1 are in bold. There were significantly lower rates for $\mathrm{Ml}$ in heterozygous genotypes of Cys-47Arg and the Gln27Glu polymorphisms in spite of the significant older age in the Gln27Glu variant. In addition, there wass also a trend for a lower rate of $\mathrm{MI}$ in the heterozygous genotype of the Arg I6Gly variation.

$\mathrm{BMI}$, body mass index; CHD, coronary heart disease; MI, myocardial infarction. 
strongly concordant, generating the haplotypes -47Cys/ $27 \mathrm{Glu}(83.5 \%$ of $-47 \mathrm{Cys}$ homozygotes are $27 \mathrm{Glu}$ homozygotes). The five most common haplotypes accounted for $73.2 \%$ of all observed haplotypes.

Use of antihypertensive or lipid-lowering medication was distributed equally in the genotype subgroups and consisted of angiotensin-converting enzyme inhibitors $(n=$ $128 ; 29.8 \%), \beta$-receptor blockers $(n=87 ; 20.3 \%)$, diuretics $(n=70 ; 16.3 \%)$, calcium-channel blockers $(n=86$; $20.0 \%)$, nitrates $(n=41 ; 9.6 \%)$ and $\alpha$-receptor blockers $(n$ $=1 ; 0.2 \%)$. Of the 40 patients on lipid-lowering medication, 37 were using statins and 3 fibrates. Total cholesterol and triglycerides measurement was available for 360 patients, and lipoprotein determination for 278 patients.

The mean \pm SD AHI in our study group was $29.1 \pm 23.1$ events per hour, and the mean minimal nocturnal oxygen saturation was $81.0 \pm 10.9 \%$. Linear and independent relationships between the $\mathrm{AHI}$ and daytime systolic and diastolic BP, daytime heart rate, the prevalence of hypertension, and HDL-C serum levels have been shown in this study group previously [4]. Because DNA tests could not be performed for all members of the parent study cohort $(n=540)$, we performed a new, adjusted regression for our subgroup of 429 subjects [7]. Multivariate linear or logistic regressions revealed a significant influence of the severity of OSA on daytime systolic BP $(\beta=0.129, P=$ $0.008)$, diastolic BP $(0.129, P=0.012)$, heart rate $(\beta=$ 0.197. $P<0.001)$ prevalence of hypertension $(\beta=0.026$, $P=<0.001)$, and HDL-C serum levels $(n=78, \beta=-0.146$, $P=0.003)[7]$. This influence was independent of diabetes, BMI, age, sex, or antidiabetic, lipid-lowering, or antihypertensive treatments.
As shown in Table 2, the $\beta 2$-adrenergic receptor polymorphisms did not modulate these relationships (Table 2; hypertension is shown in Table 1).

There were no significant differences between the $\beta 2$ adrenergic receptor genotypes in relation to BMI, AHI (not shown), medication (not shown) or the prevalence of hypertension, diabetes, dyslipidemia, and CHD. Patients heterozygous for the Gln27Glu polymorphism were significantly older than those with homozygous genotypes (Table 1).

Of the 429 patients with OSA, 27 (6.3\%) had survived a MI. Patients heterozygous for the Arg-47Cys and Gln27Glu polymorphisms showed a lower rate of survived MI than those with the homozygous forms. There was a trend towards a lower rate of survived MI in patients heterozygous for the Arg16Gly polymorphism (Table 1).

Table 3 shows the cardiovascular risk factors and diseases for the five most frequent haplotypes. Except for survived MI, there were no significant differences between the haplotypes. Haplotype 1 with heterozygosity for all three polymorphisms showed a lower rate of survived MI. As shown in Table 4, patients heterozygous for all three polymorphisms had a significantly lower relative risk (RR) for MI compared with homozygous subjects. Carriers of the most frequent haplotype $1(n=113)$, with heterozygosity for all three polymorphisms, showed a five-fold lower prevalence of survived MI $(\mathrm{OR}=0.21, P=0.023)$. When the homozygous and heterozygous states of each polymorphism were pooled into groups, the multivariate logistic regression model revealed an protective influence on survived MI, independent of age, BMI, AHI, diabetes,

Table 2: Blood pressure, heart rate and lipid levels in different genotypes of the $\beta 2$-adrenergic receptor polymorphisms.

\begin{tabular}{|c|c|c|c|c|c|c|c|c|c|c|}
\hline & $n$ & $\begin{array}{l}\mathrm{SBP} \\
\mathrm{mmHg}\end{array}$ & $\begin{array}{l}\mathrm{DBP} \\
\mathrm{mmHg}\end{array}$ & $\begin{array}{l}\mathrm{HR} \\
\text { beats/min }\end{array}$ & $n$ & $\begin{array}{l}\text { Cholesterol } \\
\mathrm{mg} / \mathrm{dl}\end{array}$ & $\begin{array}{l}\text { Triglycerides } \\
\mathrm{mg} / \mathrm{dl}\end{array}$ & $n$ & $\begin{array}{l}\mathrm{HDL} \\
\mathrm{mg} / \mathrm{dL}\end{array}$ & $\begin{array}{l}\mathrm{LDL} \\
\mathrm{mg} / \mathrm{dL}\end{array}$ \\
\hline All & 429 & $130.5 \pm 15.7$ & $79.6 \pm 9.2$ & $76.8 \pm 9.5$ & 360 & $224.7 \pm 39.4$ & $17 \mid .5 \pm 95.7$ & 278 & $46.8 \pm 14.3$ & $146.6 \pm 35.9$ \\
\hline \multicolumn{11}{|l|}{ Codon -47} \\
\hline Cys/Cys & 131 & $130 \pm 1 \pm 16.3$ & $79.8 \pm 9.4$ & $77.0 \pm 9.1$ & 112 & $226.0 \pm 40.3$ & $168.6 \pm 76.5$ & 93 & $46.0 \pm 14.3$ & $148.9 \pm 32.9$ \\
\hline Cys/Arg & 195 & $130.9 \pm 15.6$ & $79.6 \pm 9.3$ & $76.6 \pm 8.9$ & 163 & $222.5 \pm 38.5$ & $175.3 \pm 102.5$ & 123 & $47.3 \pm 13.9$ & $144.0 \pm 38.6$ \\
\hline $\operatorname{Arg} / \operatorname{Arg}$ & 103 & $130.1 \pm 15.1$ & $79.4 \pm 8.7$ & $76.9 \pm 11.0$ & 85 & $227.6 \pm 40.1$ & $167.9 \pm 105.2$ & 62 & $46.9 \pm 15.5$ & $\mid 48.3 \pm 35.1$ \\
\hline$P$ & & 0.878 & 0.942 & 0.924 & & 0.594 & 0.789 & & 0.796 & 0.578 \\
\hline \multicolumn{11}{|l|}{ Codon 16} \\
\hline Arg/Arg & 59 & $133.6 \pm 17.2$ & $80.9 \pm 9.3$ & $78.4 \pm 9.3$ & 53 & $228.2 \pm 45.7$ & $178.5 \pm 1 \mid 4.2$ & 39 & $49.7 \pm 15.9$ & $149.5 \pm 34.8$ \\
\hline Arg/Gly & 197 & $130.0 \pm 15.9$ & $79.8 \pm 9.5$ & $76.6 \pm 9.4$ & 158 & $221.4 \pm 38.6$ & $164.7 \pm 92.5$ & 123 & $47.0 \pm 14.4$ & $143 \pm 37.2$ \\
\hline Gly/Gly & 173 & $129.9 \pm 14.9$ & $79.0 \pm 8.9$ & $76.5 \pm 9.7$ & 149 & $227.2 \pm 37.8$ & $176.0 \pm 91.8$ & 116 & $45.7 \pm 13.8$ & $149.4 \pm 34.9$ \\
\hline$P$ & & 0.268 & 0.389 & 0.371 & & 0.345 & 0.496 & & 0.305 & 0.348 \\
\hline \multicolumn{11}{|l|}{ Codon 27} \\
\hline $\mathrm{Gln} / \mathrm{Gln}$ & 109 & $130.7 \pm 14.5$ & $80.2 \pm 9.0$ & $77.2 \pm 9.2$ & 93 & $222.7 \pm 42.3$ & $175.9 \pm 89.4$ & 74 & $44.9 \pm 14.0$ & $145.6 \pm 32.9$ \\
\hline Gln/Glu & 202 & $130.8 \pm 15.2$ & $79.2 \pm 9.1$ & $76.6 \pm 9.2$ & 164 & $225.3 \pm 38.3$ & $174.1 \pm 100.9$ & 128 & $47.2 \pm 14.3$ & $146.5 \pm 38.2$ \\
\hline Glu/Glu & 118 & $130.5 \pm 15.7$ & $79.9 \pm 9.5$ & $76.8 \pm 10.2$ & 103 & $224.8 \pm 39.4$ & $163.3 \pm 93.0$ & 76 & $48.0 \pm 14.8$ & $147.8 \pm 35.2$ \\
\hline$P$ & & 0.840 & 0.592 & 0.859 & & 0.841 & 0.585 & & 0.395 & 0.930 \\
\hline
\end{tabular}

Comparison of blood pressure, heart rate, lipid and lipoprotein values between the different genotypes of the $\beta 2$-adrenergic receptor polymorphisms in untreated patients with OSA. Total cholesterol and triglyceride levels were available for 360 patients and lipid electrophoresis for 278 patients. There were no significant differences between the genotypes.

SBP, systolic blood pressure; DBP, diastolic blood pressure; HDL, high-density lipoprotein; HR, heart rate; LDL, low-density lipoprotein. 
dyslipidemia, hypertension and sex [Arg-47Cys: $\beta=-1.23$, $P=0.032 ; \operatorname{Arg} 16$ Gly: $\beta=-0.94, P=0.53$; Gln27Glu: $\beta=-$ $1.12, P=0.27$; haplotype 1 (all heterozygous): $\beta=-1.555$, $P=0.04]$.

\section{Discussion}

We analysed $\beta 2$-adrenergic receptor polymorphisms in a study group of untreated patients with OSA in whom a linear and independent relationship between the frequency of nocturnal apnea/hypopnea and daytime systolic and diastolic BP, daytime heart rate, prevalence of arterial hypertension, and HDL serum levels were shown previously $[4,7]$. The elevated sympathetic nerve activity in patients with OSA [1-3] is suggested to mediate these effects, especially in relation to the cardiovascular system.

The underlying mechanisms between the severity of OSA and modulation of lipid serum level have been discussed in detail elsewhere [7]. The fact that we could not find any influence despite the sympathetic pathway supports the notion that the effect of these polymorphisms in vivo is minor, and confirms previous negative results [15]. Kim et al investigated 195 Korean subjects and found no difference between $\beta 2$-adrenergic receptor genotypes (Arg16Gly and Gln27Glu) in relation to plasma glucose, fasting serum insulin, LDL, HDL, or triglyceride levels. However, in another study of 19 healthy individuals with propanolol-induced dyslipidemia, a significantly decreased HDL serum level was found in subjects homozyous for Gln27 homozygotes, and raised triglyceride levels in subjects homozygous for Glu27 [16].
The genetic role of the $\beta 2$-adrenergic receptor gene in the development of hypertension has been the subject of many population-based studies. The distal segment of chromosome 5 (5q31.1-qtr), which harbors the $\beta 2$-adrenergic receptor gene, has been linked both to systolic and to post-exercise diastolic BP in genome-wide scans performed in large study populations $[17,18]$. In a large sample of 638 individuals from 212 Polish pedigrees, maximum linkage to essential hypertension and adjusted systolic and diastolic BP was found for a marker in close proximity to the $\beta 2$-adrenergic receptor gene. However, no significant association of the Arg16Gly and Gln27Glu polymorphisms was detected with these parameters in the same study [19].

The published studies that have shown an influence of these polymorphisms on BP and hypertension are confusing. On the one hand, the Gly16 and Glu27 genotypes were significantly associated with the prevalence of hypertension and systolic BP in two large populations of Chinese individuals $[20,21]$. On the other hand, a more than twofold increased relative risk for hypertension and higher BP was detected in homozygous Arg16 carriers with diabetes [22]. One could argue that this represents a linkage phenomenon in two different populations, but in view of the functional relevance of these polymorphisms, such contradictory results remain difficult to explain. Finally, in the most extensive and prospective population based study, the Cardiovascular Health Study, with over 5000 participants, no effect of the Arg16Gly and Gln27Glu polymorphisms on BP control, new-onset hypertension, ankle-arm index, carotide intima-media thickness, or brachial flow-mediated dilation was

Table 3: Risk factors, coronary heart disease and myocardial infarction in haplotypes of the $\beta 2$-adrenergic receptor.

\begin{tabular}{|c|c|c|c|c|c|c|}
\hline \multicolumn{7}{|c|}{ All } \\
\hline & & Haplotype I & Haplotype 2 & Haplotype 3 & Haplotype 4 & Haplotype 5 \\
\hline$n(\%)$ & 429 & II3 (26.3) & $78(18.2)$ & $47(1 \mathrm{I} .0)$ & $42(9.8)$ & $34(7.9)$ \\
\hline Diabetes, $n$ (\% of Hap.) & $74(17.2)$ & $21(18.6)$ & $12(15.4)$ & $7(14.9)$ & $10(23.8)$ & $5(14.7)$ \\
\hline Hypertension,, $n$ (\% of pt) & $258(60.1)$ & $70(61.9)$ & $48(6 \mid .5)$ & $25(53.2)$ & $24(57.1)$ & $21(61.8)$ \\
\hline Dyslipidemia $n$ (\% of Hap.) & $211(49.2)$ & $49(43.4)$ & $38(48.7)$ & $21(44.7)$ & $22(52.4)$ & $16(47.1)$ \\
\hline CHD, $n$ (\% of Hap.) & $55(12.8)$ & $14(12.4)$ & $9(11.5)$ & $7(14.9)$ & $3(7.1)$ & $4(1 \mathrm{I} .8)$ \\
\hline \multirow[t]{2}{*}{ MI, $n$ (\% of Hap.) } & $27(6.3)$ & $2(1.8)$ & $6(7.7)$ & $3(6.4)$ & $3(7.1)$ & $4(11.8)$ \\
\hline & & $P=0.021$ & & & & \\
\hline
\end{tabular}

- Haplotype I: T/C at position -47, A/G at position I6, C/G at position 27.

- haplotype 2: $\mathrm{C} / \mathrm{C}$ at position $-47, \mathrm{G} / \mathrm{G}$ at position $16, \mathrm{G} / \mathrm{G}$ at position 27.

- haplotype 3: T/C at position -47, G/G at position I6, C/G at position 27.

- haplotype 4: T/T at position -47, A/G at position 16, C/C at position 27.

- haplotype 5: T/T at position -47, A/A at position 16, C/C at position 27.

Distribution of cardiovascular risk factors, $\mathrm{CHD}$ and $\mathrm{MI}$ in the five most frequent statistical haplotypes of the three $\beta 2$-adrenergic receptor polymorphisms. Comparisons between the haplotypes were performed with the $\chi^{2}$ test. Haplotype I, with heterozygosity in all three polymorphisms, showed a significant $(P=0.02 I)$ lower rate of $M I[n=I I 3, M I=2(I .8 \%])$ compared with the rest of the study group $[n=3 \mid 6, M I$ $=25(7.9 \%)]$. This corresponds to an odds ratio of 0.21 . There were no additional significant relations between clinical diagnoses and the $\beta 2-$ adrenergic receptor haplotypes. Furthermore, no significant differences in blood pressure, heart rate or lipid levels, respectively, existed between the different haplotypes (results not shown). Significant $P$ factor is shown in bold.

$\mathrm{CHD}$, coronary heart disease; Hap., haplotype; $\mathrm{MI}$, myocardial infarction. 
Table 4: Relative risk for myocardial infarction in OSA patients heterozygous for $\beta 2$-adrenergic receptor polymorphisms.

\begin{tabular}{lllr}
\hline & $n(\%)$ & Relative risk for myocardial infarction: odds ratio (95\% confidence interval) & $P$ \\
\hline All & 429 & & $\mathbf{0 . 0 1 2}$ \\
Heterozygote: Cys-47Arg & $195(45.2)$ & $0.32(0.13-0.82)$ & $\mathbf{0 . 0 3 I}$ \\
Heterozygote: Arg16Gly & $197(45.9)$ & $0.39(0.16-0.94)$ & $\mathbf{0 . 0 2 3}$ \\
Heterozygote: GIn27Glu & $202(47.1)$ & $0.37(0.15-0.89)$ & $\mathbf{0 . 0 2 3}$ \\
Haplotype Cys-47Arg/Arg16Gly/Gln27Glu & $113(26.3)$ & $0.21(0.05-0.90)$ & \\
\hline
\end{tabular}

Significant $P$ factors are shown in bold.

detected [23]. Interestingly, in this study cohort, Glu27 carriers (heterozygous and homozygous) had a significantly lower risk for coronary events, and there was a similar trend for Gly16 carriers [24]. Recently, in the same study population, it was shown that Glu27 carriers also have a significantly lower risk for sudden cardiac death [25].

In contrast to the aforementioned studies, we investigated a cohort of patients in which an OSA-induced, elevated sympathetic activity exacerbated $\mathrm{BP}$, heart rate, and HDL levels. Thus, the known functional relevance of these polymorphisms in vitro would be likely to be detected in vivo in such patients. The fact that we could not detect any significant result underlines the minor effect of $\beta 2$-adrenergic receptor polymorphisms in the development of these cardiovascular risk factors, and supports the results of the Cardiovascular Health Study.

Sympathetic activation also influences the risk of MI [26]. Thus, patients with OSA show a higher incidence of fatal and non-fatal cardiovascular events [9]. In our study group, with a mean age of 56 years, we found a high percentage of CHD (12.8\%) and survived MI (6.3\%). Although no effect was seen on the prevalence of CHD, we found a clear and independent protective effect of the heterozygous $\beta 2$-adrenergic receptor genotypes on survived MI. This result again supports the hypothesis that was deducted form the Cardiovascular Health Study; namely, that variations of the $\beta 2$-adrenergic receptor gene influence vulnerability to coronary events.

In the statistical model that was chosen in the Cardiovascular Health Study, carriers of the Gly variation were pooled into one group. It is not apparent whether heterozygosity alone is protective, but a protective effect of heterozygosity in the $\beta 2$-adrenergic receptor has already been shown in pulmonary research. Joos et al examined 587 smokers from the Lung Health Study. Those subjects who were heterozygous at position 27 of the $\beta 2$-adrenergic receptor gene had a significantly lower decline in lung function at 1-year follow-up compared with the homozygous genotypes $(P<0.001)$ [27]. Our results sup- port those findings; by pooling homozygous and heterozygous individuals into two different groups, we could show a protective effect of heterozygosity on MI, independent of other risk factors such as diabetes, arterial hypertension, dyslipidemia and BMI in a logistic regression model. Interestingly, patients heterozygous at position 27 were slightly but significantly older in spite of the lower rate of MI (Table 1). This may be an additional indicator for the protective effect of this polymorphism.

As discussed previously by Loos et al, [27] a reason for the protective effect of heterozygosity may be a phenomenon called heterozygous advantage. For example, a study on the role of the secretor blood group in psoriasis showed that heterozygosity had a strong protective effect (odds ratio $=0.17$ ), even though the allele frequencies did not differ between patients and controls [28]. A possible mechanism for heterozygote advantage is interaction between the wild-type and mutant protein isoforms in heterozygous cells. This is a plausible mechanism for receptor molecules, especially in cases where they form dimers. Heterodimeric receptors consisting of a wild-type and a mutant protein isoform may have different agonistbinding, signal-transduction or agonist-promoted desensitation properties than wild-type or mutant homodimers. Several lines of evidence indicate that $\beta 2$-adrenergic receptors form dimers like other G-protein-coupled receptors. The formation of $\beta 2$-adrenergic receptor dimers was shown to have functional effects on receptor-stimulated adenylate cyclase activity [29]. Furthermore, the results of a study of a mutant $\beta 2$-adrenergic receptor (Cys341Gly) suggested that the dimer is the active form of the receptor [30].

\section{Limitations of the study}

Lipid and lipoprotein serum levels were not available for all patients. Therefore, the diagnosis of dyslipidemia had to be determined by anamnesis alone in some cases, which may have led to inaccuracies in the multivariate regression. The diagnosis of CHD was determined by anamnesis and was not controlled by coronary arteriography. Thus, our proportion of $12.8 \%$ may not reflect the real incidence of CHD. 
Because our hypothesis included several risk factors for CHD and MI, Bonferroni correction after the statistical analysis should be discussed. After this correction, the results for MI would become insignificant. Because of the explorative character of our study, we refrained from performing Bonferroni corrections here.

\section{Conclusion}

We conclude that the investigated $\beta 2$-adrenergic receptor polymorphisms do not modulate cardiovascular risk factors in patients with OSA-induced elevated sympathetic activity. However, heterozygosity of these polymorphisms may be protective in reducing the vulnerability to survived MI, especially if heterozygosity is present for all polymorphisms. Because the statistical haplotype with heterozygosity in all three polymorphisms was not included in previous studies, we believe that this potentially protective genetic combination should be focussed on in future.

\section{Competing interests}

The author(s) declare that they have no competing interests.

\section{Authors' contributions}

N.K.B. and J.B. developed the study design, carried out the molecular genetic studies, participated in the statistical analysis, drafted and edited the manuscript. S.W. participated in the DNA isolation and assisted in the SSCP-analysis. J.T.E. participated in the study design and supervised the genetic research procedures, N.B., B.M.S, D.B. and L.C.R. organized the patient collection, developed the patient's queries and participated in the management of the clinical data. C.H. and A.M. participated in the statistical analysis and in editing of the manuscript.

\section{Acknowledgements}

This study was supported by FoRUM (Forschungsförderung der Ruhr-Universität Bochum, Medizinische Fakultät). We thank Michael Haske, Dr. med. Christina Giese and Dr. med. Marion Burmann-Urbaneck for support in patient recruitment and Mrs Anika Huesing for assistance in statistical analysis.

\section{References}

I. Somers VK, Dyken ME, Clary MP, Abboud FM: Sympathetic neural mechanisms in obstructive sleep apnea. J Clin Invest 1995, 96: $1897-904$.

2. Lesske J, Fletcher EC, Bao G, Unger T: Hypertension caused by chronic intermittent hypoxia - influence of chemoreceptors and sympathetic nervous system. J Hypertens 1997, I 5:1593-603.

3. Narkiewicz K, Somers VK: Sympathetic nerve activity in obstructive sleep apnoea. Acta Physiol Scand 2003, I 77:385-90.

4. Börgel J, Sanner BM, Keskin F, Bittlinsky A, Bartels NK, Büchner N, Huesing $A$, Rump LC, Mügge $A$ : Obstructive sleep apnea and blood Pressure. Interaction between the blood pressurelowering effects of positive airway pressure therapy and antihypertensive drugs. Am J Hypertens 2004, I 7: 1081-1087.

5. Peppard PE, Young T, Palta M, Skatrud J: Prospective study of the association between sleep-disordered breathing and hypertension. N Engl J Med 2000, 342:|378-84.
6. Newman AB, Nieto FJ, Guidry U, Lind BK, Redline S, Pickering TG, Quan SF: Relation of sleep-disordered breathing to cardiovascular disease risk factors: the Sleep Heart Health Study. Am J Epidemiol 200 I, I 54:50-9.

7. Börgel J, Sanner BM, Bittlinsky A, Keskin F, Bartels NK, Büchner N, Huesing A, Rump LC, Mugge A: Obstructive sleep apnoea and its therapy influence high density lipoprotein cholesterol serum levels. Eur Respir J 2006, 27:121-127.

8. Shahar E, Whitney CW, Redline S, Lee ET, Newman AB, Javier Nieto F, O'Connor GT, Boland LL, Schwartz JE, Samet JM: Sleep-disordered breathing and cardiovascular disease: cross-sectional results of the Sleep Heart Health Study. Am J Respir Crit Care Med 2001, 163:19-25.

9. Marin J, Carrizo S, Vicente E, Agusti A: Long-term cardiovascular outcomes in men with obstructive sleep apnoea-hypopnoea with or without treatment with continuous positive airway pressure: an observational study. Lancet 2005, 365:1046-1053.

10. Lavie P, Herer P, Peled R, Berger I, Yoffe N, Zomer J, Rubin AH: Mortality in sleep apnea patients: a multivariate analysis of risk factors. Sleep 1995, I 8: |49-57.

II. Liggett SB: Beta(2)-adrenergic receptor pharmacogenetics. Am J Respir Crit Care Med 2000, I 6 I: 197-20I.

12. McGraw DW, Forbes SL, Kramer LA, Liggett SB: Polymorphisms of the 5' leader cistron of the human beta2-adrenergic receptor regulate receptor expression. J Clin Invest 1998, 102:1927-32.

13. Johnatty SE, Abdellatif M, Shimmin L, Clark RB, Boerwinkle E: Beta 2 adrenergic receptor $5^{\prime}$ haplotypes influence promoter activity. Br J Pharmacol 2002, I37:1213-6.

14. Green SA, Turki J, Innis M, Liggett SB: Amino-terminal polymorphisms of the human beta2-adrenergic receptor impart distinct agonist-promoted regulatory properties. Biochemistry 1994, 33:9414-9.

15. Kim SH, Kim DJ, Seo IA, Min YK, Lee MS, Kim KW, Lee MK: Significance of beta2-adrenergic receptor gene polymorphism in obesity and type 2 diabetes mellitus in Korean subjects. Metabolism 2002, 5 I :833-7.

16. Isaza C, Henao J, Ramirez E, Cuesta F, Cacabelos R: Polymorphic variants of the beta2-adrenergic receptor (ADRB2) gene and ADRB2-relateted propanolol-induced dyslipidemia in the Colombian population. Methods Find Exp Clin Pharmacol 2005, 27:237-244.

17. Krushkal J, Ferrell R, Mockrin S, Turner ST, Sing CF, Boerwinkle E: Genome-wide linkage analyses of systolic blood pressure using highly discordant siblings. Circulation 1999, 99:|407-1410.

18. Rankinen T, An P, Rice T, Sun G, Chagnon YC, Gagnon J, Leon AS, Skinner JS, Wilmore JH, Rao DC, et al.: Genomic scan for exercise blood pressure in the Health, Risk Factors, Exercise Training and Genetics (HERITAGE) Family Study. Hypertension 200I, 38:30-37.

19. Tomaszewski M, Brain NJ, Charchar FJ, Wang WY, Lacka B, Padmanabahn S, Clark JS, Anderson NH, Edwards HV, Zukowska-Szczechowska E, et al.: Essential hypertension and beta2adrenergic receptor gene: linkage and association analysis. Hypertension 2002, 40:286-91.

20. Ranade K, Shue WH, Hung YJ, Hsuing CA, Chiang FT, Pesich R, Hebert J, Olivier M, Chen YD, Pratt R, et al.: The glycine allele of a glycine/arginine polymorphism in the beta2-adrenergic receptor gene is associated with essential hypertension in a population of Chinese origin. Am J Hypertens 200I, I 4: I I 96-200.

21. Ge D, Huang J, He J, Li B, Duan X, Chen R, Gu D: B2-Adrenergic receptor gene variations associated with stage- 2 hypertension in Northern Han Chinese. Ann Hum Genet 2005, 69:36-44.

22. Bengtsson K, Orho-Melander M, Melander O, Lindblad U, Ranstam J, Rastam L, Groop L: Beta(2)-adrenergic receptor gene variation and hypertension in subjects with type 2 diabetes. Hypertension 200I, 37: 1303-8.

23. Hindorff LA, Heckbert SR, Psaty BM, Lumley T, Siscovick DS, Herrington DM, Edwards KL, Tracy RP: 32 -adrenergic receptor polymorphisms and determinants of cardiovascular risk: The Cardiovascular Health Study. Am J Hypertens 2005, I 8:392-397.

24. Heckbert SR, Hindorff LA, Edwards KL, Psaty BM, Lumley T, Siscovick DS, Tang Z, Durda JP, Kronmal RA, Tracy RP: Beta2-adrenergic receptor polymorphisms and risk of incident cardiovascular events in the elderly. Circulation 2003, 107:202 I-4. 
25. Sotoodehnia N, Sicovick DS, Vatta M, Psaty BM, Tracy RP, Towbin JA, Lemaitre RN, Rea TD, Durda JP, Chang JM, et al.: Beta2-adrenergic receptor genetic variants and risk of sudden cardiac death. Circulation 2006, I| 3:1818-1820.

26. Albert CM, Mittleman MD, Chae CU, Lee IM, Hennekens CH, Manson JE: Triggering of sudden death from cardiac causes by vigorous exertion. $N$ Engl J Med 2000, 343:|355-|36|.

27. Joos L, Weir TD, Connett JE, Anthonisen NR, Woods R, Pare PD, Sandford AJ: Polymorphisms in the beta2 adrenergic receptor and bronchodilator response, bronchial hyperresponsiveness, and rate of decline in lung function in smokers. Thorax 2003, 58:703-7.

28. Beckmann L, Bronnestam R, Cedergren B, Liden S: HL-A antigens, blood groups, serum groups and red cell enzyme thypes in psoriasis. Hum Hered 1974, 24:496-506.

29. Hebert TE, Moffett S, Morello JP, Loisel TP, Bichet DG, Barret C, Bouvier M: A Peptide derived from a $\beta 2$-adrenergic receptor transmembrane domain inhibits both receptor dimerization and activation. J Biol Chem 1996, 27 I:16384-16392.

30. Hebert TE, Loisel TP, Adam L, Ethier N, Onge SS, Bouvier M: Functional rescue of a constitutively desensitized beta2AR through receptor dimerization. Biochem J 1998, I5:287-293.

\section{Pre-publication history}

The pre-publication history for this paper can be accessed here:

http://www.biomedcentral.com/1741-7015/5/1/prepub

Publish with Bio Med Central and every scientist can read your work free of charge

"BioMed Central will be the most significant development for disseminating the results of biomedical research in our lifetime. "

Sir Paul Nurse, Cancer Research UK

Your research papers will be:

- available free of charge to the entire biomedical community

- peer reviewed and published immediately upon acceptance

- cited in PubMed and archived on PubMed Central

- yours - you keep the copyright 